\title{
Eco-efficient alkaline activated binders for manufacturing blocks and pedestrian pavers with low carbon footprint: Mechanical properties and LCA assessment
}

\author{
J. Mejía-Arcila $\bowtie$, W. Valencia-Saavedra, R. Mejía de Gutiérrez \\ Composites Materials Group (GMC), School of Materials Engineering, Universidad del Valle, (Cali, Colombia) \\ $\triangle$ johanna.mejia@correounivalle.edu.co
}

Received 20 December 2019 Accepted 1 June 2020

Available on line 20 October 2020

\begin{abstract}
This study proposes using two types of binders based on fly ash (FA) as primary raw material and a calcium source such as ground granulated blast furnace slag (GBFS) or Portland cement (OPC) for the production of eco-efficient pre-fabricated materials. These binders are denoted FA/GBFS (70/30) and FA/OPC (80/20). A mix of commercial sodium silicate and sodium hydroxide was used as a traditional activator (SN), and the mix of rice husk ash (RHA) and $\mathrm{NaOH}$ as an alternative activator (RN). The results show the possibility of obtaining a binary cement (FA/GBFS-RN) with compressive strength up to $38 \mathrm{MPa}$ after curing for 28 days and $65 \mathrm{MPa}$ after curing for 360 days. The hybrid binder (FA/OPC-RN) reported $30 \mathrm{MPa}$ and $61 \mathrm{MPa}$ at the same age of curing. Additionally, FA/GBFS-RN reports reductions in the environmental and health impacts of up to $75 \%$ compared to systems made with sodium silicate and sodium hydroxide. Based on the results, FA/ GBFS-RN paste was selected as the optimal material for producing masonry blocks and pedestrian pavers, which met the Colombian standards.
\end{abstract}

KEYWORDS: Fly ash; Rice husk ash; Alkaline-activated cement; Life cycle assessment; Precast elements.

Citation/Citar como: Mejía-Arcila, J.; Valencia-Saavedra. W., Mejía de Gutiérrez, R. (2020) Eco-efficient alkaline activated binders for manufacturing blocks and pedestrian pavers with low carbon footprint: Mechanical properties and LCA assessment. Mater. Construcc. 70 [340], e232 https://doi.org/10.3989/mc.2020.17419

RESUMEN: Materiales cementantes activados alcalinamente para la fabricación de bloques y adoquines peatonales con baja huella de carbono: Propiedades mecánicas y análisis LCA. Este estudio propone el uso de dos tipos de aglomerantes basados en ceniza volante como materia prima principal (FA) y una fuente de calcio, tal como escoria de alto horno (GBFS) o cemento Portland (OPC) para la producción de materiales prefabricados ecoeficientes. Los cementantes se denominaron FA/GBFS (70/30) y FA/OPC (80/20). Como activadores se emplearon, uno tradicional que consistió en la mezcla de silicato de sodio con hidróxido de sodio (SN) y uno alternativo, correspondiente a la mezcla de ceniza de cascarilla de arroz (RHA) e hidróxido de sodio (RN). Los resultados muestran la posibilidad de obtener un cementante binario (FA/GBFS-RN) con resistencias a la compresión de hasta $38 \mathrm{MPa}$ a los 28 días y $65 \mathrm{MPa}$ a 360 días. El cementante hibrido (FA/OPC-RN) reportó $30 \mathrm{MPa}$ y 61 $\mathrm{MPa}$ a la misma edad de curado. Adicionalmente, FA/GBFS-RN reportó reducciones de hasta un $75 \%$ en el impacto ambiental y de salud en comparación con los sistemas fabricados con silicato de sodio e hidróxido de sodio. Basados en los resultados, la pasta (FA/GBFS-RN) fue seleccionada para la producción de bloques de mampostería y adoquines peatonales, los cuales cumplieron las normas técnicas colombianas.

PALABRAS CLAVE: Cenizas volantes; Cenizas de cascarilla de arroz; Cemento álcali-activado; Análisis de ciclo de vida; Elementos prefabricados.

ORCID ID: J. Mejía-Arcila (https://orcid.org/0000-0001-5754-4162); W. Valencia-Saavedra (https://orcid.org/00000002-8918-2132); R. Mejía de Gutiérrez (https://orcid.org/0000-0002-5404-2738).

Copyright: (C) 2020 CSIC. This is an open-access article distributed under the terms of the Creative Commons Attribution 4.0 International (CC BY 4.0) License. 


\section{INTRODUCTION}

At the global level, pre- and post-consumption wastes are being reincorporated into manufacturing processes using the circular economy strategy, which focuses on reducing the use of natural materials and minimizing waste generation. Alkaline activation can be used to promote a circular economy in the field of construction materials, as alternative cementitious materials can be manufactured with low environmental impacts. This technology makes it possible to use industrial and agro-industrial wastes as raw materials, which reduces the use of non-renewable natural resources, minimizes the impact of quarry and inappropriate land use, and reduces landfill volumes. Alkaline-activated materials have attracted attention because, in addition to their mechanical properties and high chemical resistance, they can, in some cases, be less expensive to produce than traditional construction materials. Additionally, depending on the type of precursor and activator, they can generate low environmental impact compared to conventional materials based on Portland cement. Habert and Ouellet-Plamondon (1) reported that concrete based on alkali-activated cements could contribute to reducing by a factor of 4 the $\mathrm{CO}_{2}$ emissions associated with the concrete production. However, other environmental categories were detected to have negative impacts, although the authors consider that these categories are less critical for the construction industry. These results can be considered an opportunity for manufacturers acquiring international certifications such as Cradle to Cradle $\AA$, LEED $\AA$, BREEAM, among others, are awarded credits if waste is used as a raw material and if environmental and health impacts are reduced with respect to traditional materials.

FA is a coal combustion product obtained from boilers and thermoelectric plants. The annual worldwide production is about 750 to $800 \mathrm{Mt}(2-4)$. China, India, and the USA are the largest consumer of coal, and consequently, the biggest generators of FA. Depending on the country, the consumption of FA varies from 3\% to $90 \%$ (2). Although FA can be used in diverse applications (cementitious materials, bricks, geopolymers, zeolites, recover of metals, catalysts, glass-ceramics, soil stabilization, road construction, aerogels, and others), it is estimate that more than $60 \%$ of FA produced globally is disposed of in landfills $(3,4)$.

Most studies have examined high-quality fly ash (FA) with lower amounts of unburned carbon in order to produce construction elements based on alkaline activation technology. Palomo and Fernández-Jiménez (5) manufactured fly ash-based concrete blocks like those produced with Portland cement. In other study, the same authors (6) fabricated monoblock railway sleepers from an alkaline cementitious material composed of $100 \%$ fly ash.
Kishan and Radhakrishna (7) used a binary mixture of fly ash and blast furnace slag to produce masonry blocks, and Arioz et al. (8) used fly ash to form bricks using a pressure method. In general, the previously mentioned studies used sodium silicate and sodium hydroxide as alkaline activators, causing the carbon footprint of the material to be similar to or, in some cases, lower than that of traditional materials such as Portland cement which is made with natural raw materials.

Considering that the manufacture of sodium silicate is energy-intensive and generates $\mathrm{CO}_{2}$ emissions, in the last years, the studies have focused on the search for alternative activators. Industrial byproducts and wastes have been studied, such as rice husk ash (RHA) (9), waste glass (10), diatomaceous earth (11), silica fume (12), among others.

Rice husk ash obtained at $600^{\circ} \mathrm{C}$ was used to produce sodium waterglass with different molar ratios $\mathrm{SiO}_{2} / \mathrm{Na}_{2} \mathrm{O}$ (0.31-1.25), which were used as activators of metakaolin-based geopolymers (13). The maximum compressive strength $(36 \mathrm{MPa}$ at 28 d) was obtained with a molar ratio of 1.25 . The lower strength of the other proportions was attributed to the reduction of the soluble silica in the mixtures (13). Luukkonen et al. (12) evaluated RHA and microsilica (MS) as solid activators of one-part alkali-activated blast furnace slag mortar, although the alkali-solubility of RHA and MS is lower than that of sodium meta silicate, the compressive strength reported were 32 and $34 \mathrm{MPa}$ at 28 days. Mellado et al. (14) evaluated the emissions of a geopolymer mortar produced with a fluid catalytic cracking catalyst (FCC) and proved that the use of RHA-derived waterglass led to reduced $\mathrm{CO}_{2}$ emission by $50 \%$ compared to the geopolymer mortar prepared with commercial waterglass. Tchakoute et al. (15) compared the compressive strength of a MK-based geopolymer binder using sodium waterglass from $\mathrm{RHA}\left(83 \% \mathrm{SiO}_{2}\right.$ amorphous) and glass waste with molar ratio $\mathrm{SiO}_{2} / \mathrm{Na}_{2} \mathrm{O}$ equal to 1.5 . The maximum compressive strength was measured in a geopolymer binder activated with glass waste; this is attributed to the presence of calcium ions, which contributes to the formation of a high cross-linking geopolymer. In another study, Tchakoute et al. (16) use sugar cane bagasse ash to produce waterglass, which was used as an activator of MK-based geopolymer. The compressive strength obtained after 28 days of curing was 31.4 MPa, value comparable to those obtained with RHA in previous studies (13). Passuello et al. (17) based on a life cycle analysis (LCA) reported a reduction of more than $70 \%$ in the Global Warming Potential (GWP) and approximately $60 \%$ in other impact categories when is used RHA compared to a commercial silicate in the production of geopolymers. In general, the different reports agree that sodium silicate from RHA is a viable substitute for 
the commercial sodium silicate, with advantages such as its availability and the potential reduction of environmental impact (18).

The objective of this study was to demonstrate the feasibility of using an alkali-activated mortar to produce masonry blocks and pedestrian pavers that meet the technical standards required in the Colombian construction industry. Additionally, the study proposes to reduce the environmental impact of the alkali-activated binders by using precursors and activators from by-products and wastes generated in the local industries. The fly ash (FA) used as primary raw material came from a thermoelectric power station, it has a high unburned content $(14.96 \%)$ being classified as a low-quality fly ash. An agro-industrial waste, rice husk ash (RHA), generated in a combustor that uses rice husk as fuel, was used to prepare an alternative alkali-activator. Ground granulated blast furnace slag (GBFS) and ordinary Portland cement (OPC) were used as calcium sources. Two types of activators were used, a commercial sodium silicate and an alternative sodium silicate produced mixing RHA and sodium hydroxide. The compressive strength of the binary (FA/GBFS) and hybrid (FA/OPC) pastes was tested at ages up to 360 days, and the life cycle analysis (LCA) methodology was employed as an eco-criteria to determine the optimum cementitious binder to be applied as a base to fabricate an eco-efficient mortar to manufacture construction elements.

\section{MATERIALS AND EXPERIMENTAL PROCEDURE}

\subsection{Materials}

FA and GBFS were used as precursors to manufacture alkaline-activated binders and mortars. The FA and GBFS used in this study were industrial byproducts supplied by a thermoelectric plant and a Colombian steel factory, respectively. FA and GBFS were subjected to a conditioning process by grinding in a ball mill to reduce its particle size. Table 1 shows

TABLE 1. Chemical composition of the raw materials.

\begin{tabular}{lrrrr}
\hline $\begin{array}{l}\text { Chemical } \\
\text { compound (\% wt) }\end{array}$ & FA & GBFS & OPC & RHA \\
\hline $\mathrm{SiO}_{2}$ & 54.30 & 32.32 & 20.20 & 96.02 \\
$\mathrm{Al}_{2} \mathrm{O}_{3}$ & 21.74 & 14.65 & 7.00 & 0.20 \\
$\mathrm{Fe}_{2} \mathrm{O}_{3}$ & 4.55 & 1.11 & 4.80 & 0.20 \\
$\mathrm{CaO}$ & 0.81 & 47.37 & 58.40 & 0.00 \\
$\mathrm{TiO}_{2}$ & 1.01 & 0.51 & - & 0.00 \\
$\mathrm{~K}_{2} \mathrm{O}$ & 1.42 & 0.40 & - & 0.00 \\
$\mathrm{~S}$ & 0.61 & 0.81 & - & 0.00 \\
$\mathrm{MgO}$ & 0.61 & 1.01 & - & 0.00 \\
$\mathrm{LOI}$ & 14.96 & 1.82 & 9.60 & 3.57 \\
\hline
\end{tabular}

the chemical composition of the FA, GBFS, and OPC used to produce the binary and hybrid binders. The chemical composition of the precursors was determined using X-ray fluorescence analysis by a Malvern Panalytical Axios ${ }^{\mathrm{mAX}}$ spectrometer. It is worth noting the high content of unburned carbon $(14.96 \%)$ contained in the fly ash (FA). The particle size distribution was carried out in a laser particle size analyzer (Malvern Mastersizer, 2000). The particle size distribution of the raw materials is shown in Figure 1. The average particle size D[4,3] of FA and GBFS was $19.50 \mu \mathrm{m}$ and $17.79 \mu \mathrm{m}$, respectively.

A commercial sodium silicate (SS) and an alternative activator based on RHA as silica source were used as the activators in this study; in both cases, sodium hydroxide $(\mathrm{NaOH}$ : analytical grade, $99 \%$ purity, Merck) was used to adjust the proportion of sodium in the alkaline solution. The chemical composition of the industrial $\mathrm{SS}$ was $32.4 \% \mathrm{SiO}_{2}, 13.5 \%$ $\mathrm{Na}_{2} \mathrm{O}$, and $54.1 \% \mathrm{H}_{2} \mathrm{O}$. The RHA used in this study is an agro-industrial by-product obtained from the burning of rice husks used as biomass fuel. RHA has a high silica content (96\%), as shown in Table 1; however, applying the method developed by Mehta (19), only $36 \%$ of the silica in RHA is considered reactive or soluble in an alkaline medium $(\mathrm{NaOH}$ solution). The low percentage of soluble silica is due to the lack of control in the combustion process. The average particle size of RHA (D[4,3]) after the grinding treatment for about 15 minutes in a planetary ball mill, was of $5 \mu \mathrm{m}$; this material shows a bimodal curve (Figure 1).

The alternative alkaline activator $(\mathrm{NaOH}+\mathrm{RHA})$ was obtained mixing the silica source (i.e., RHA) with a sodium hydroxide solution, in order to obtain a molar ratio $\mathrm{SiO}_{2} / \mathrm{Na}_{2} \mathrm{O}$ or solution modulus $(\mathrm{Ms})$ equal to 1.5 in the FA/OPC-RN geopolymer and

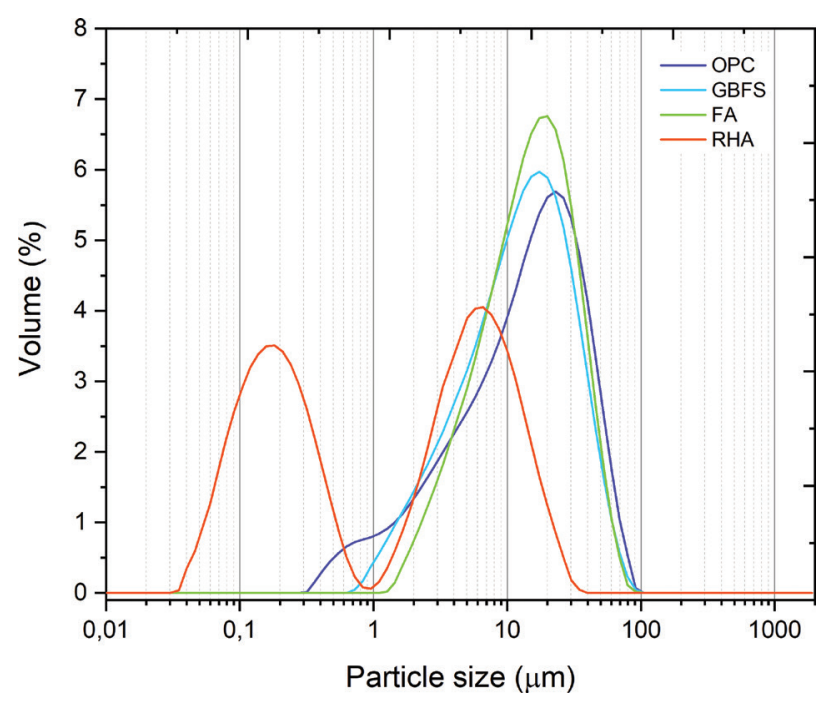

FIGURE 1. Particle size distribution of the raw materials. 
TABLE 2. Binders and their respective molar ratios.

\begin{tabular}{|c|c|c|c|c|}
\hline \multirow[b]{2}{*}{ Systems } & \multirow[b]{2}{*}{$\begin{array}{l}\text { Alkaline } \\
\text { activator }\end{array}$} & \multirow{2}{*}{$\begin{array}{c}\mathbf{M}_{\mathrm{S}} \\
\mathrm{SiO}_{2} I \\
\mathrm{Na}_{2} \mathbf{O} \\
\end{array}$} & \multicolumn{2}{|c|}{$\begin{array}{c}\text { Molar ratio of the } \\
\text { binder }\end{array}$} \\
\hline & & & $\begin{array}{l}\mathrm{SiO}_{2} l \\
\mathrm{Al}_{2} \mathrm{O}_{3}\end{array}$ & $\begin{array}{l}\mathrm{Na}_{2} \mathrm{O} / \\
\mathrm{SiO}_{2}\end{array}$ \\
\hline FA/GBFS- SN & $\mathrm{SS}+\mathrm{NaOH}$ & 1.2 & 5.4 & \multirow{4}{*}{0.2} \\
\hline FA/OPC- SN & & 1.5 & 6.0 & \\
\hline FA/GBFS-RN & $\mathrm{RHA}+\mathrm{NaOH}$ & 1.2 & 5.4 & \\
\hline FA/OPC- RN & & 1.5 & 6.0 & \\
\hline
\end{tabular}

1.2 in the FA/GBFS-RN geopolymer (Table 2). These molar ratios were also used in mixtures activated with $\mathrm{SN}$. This means that the purpose was to replace the total amount of $\mathrm{SiO}_{2}$ from commercial sodium silicate with silica from RHA. It should be noted that the contribution of $\mathrm{SiO}_{2}$ from RHA was considered as $96 \%$, taking into account the chemical composition listed in Table 1. The solution modulus (Ms) used in this study are in accordance with those used by Tchakoute et al. (13) to produce MK-based geopolymers and activated with waterglass from RHA. The alkali activators RN and $\mathrm{SN}$ were stored at room temperature for one day before its use. The $\mathrm{pH}$ of the activator solutions SN and $\mathrm{RN}$ was in the range of 12.2 to 12.7.

\subsection{Methods}

Two types of binders were produced, a binary binder FA/GBFS with a 70/30 proportion and a hybrid binder FA/OPC with an 80/20 proportion; each mixture was activated with the two alkaline activators ( $\mathrm{SN}$ and $\mathrm{RN}$ ). The $\mathrm{SiO}_{2} / \mathrm{Al}_{2} \mathrm{O}_{3}$ and $\mathrm{Na}_{2} \mathrm{O} / \mathrm{SiO}_{2}$ molar ratios and solution modulus $\mathrm{M}_{\mathrm{S}}\left(\mathrm{SiO}_{2} / \mathrm{Na}_{2} \mathrm{O}\right)$ used to prepare each binder are presented in Table 2, where RN corresponds to the mixture of RHA and $\mathrm{NaOH}$, and $\mathrm{SN}$ corresponds to the solution mixture of commercial SS and $\mathrm{NaOH}$. The mix proportions were calculated using the chemical composition of precursors and activators in order to obtain the molar ratios specified in Table 2. The liquid/solid ratio (L/S) where $\mathrm{L}$ represents the water content added and the provided by the activator, and $\mathrm{S}$ includes the precursors and the activator anhydrous, varies depending on the workability of the paste. FA/GBFS-SN, FA/OPC $\mathrm{SN}$ and RN type were prepared using a L/S of 0.35 , FA/GBFS-RN was prepared with L/S of 0.42 .

The cementitious paste was elaborated, mixing all the components in a Hobart mixer for approximately 10 minutes; the resulting paste was poured into cubic moulds of $20 \mathrm{~mm}$ per side. The specimens were cured in a chamber at room temperature with a relative humidity greater than $90 \%$.

The prefabricated elements (blocks and pavers) were manufactured following the same steps mentioned above, the solid precursors FA/GBFS were mixed with the alkaline activator $(\mathrm{RN})$ for about five (5) minutes to make a binder. Afterward, river sand was added to the binder to make a mortar; the mixing process continued to complete $10 \mathrm{~min}$ utes. The blocks were cast in a manual compression machine "Cinva-Ram machine" used to make soilcement blocks, and the pavers were manufactured in a vibratory compactor machine. Both elements were kept covered with a plastic film to avoid water release from the material; all the elements were cured in a climatic chamber at controlled conditions $\left(25^{\circ} \mathrm{C}\right.$ and $90 \%$ H.R). The sand used was from the river with a maximum particle size of $1.18 \mathrm{~mm}$ (mesh No 16). The L/S ratio for blocks and pavers was 0.45 and 0.38 , respectively.

Microstructural analysis, physical, and mechanical tests were performed as follow:

- The microstructure of the alkaline activated pastes at the ages of 28 and 360 days was characterized using a JEOL JSM-6490LV scanning electron microscope (SEM) under a high vacuum $\left(3 \times 10^{-6}\right.$ torr $)$, and the SEM was fitted with an Oxford Instruments 7573 Inca PentaFETx3 detector. The chemical elemental analysis was conducted using energy-dispersive X-ray spectroscopy (EDX). The samples before the test were coat with gold without polishing.

- Solid-state NMR: ${ }^{29} \mathrm{Si}$ NMR experiments were measured on a Bruker 400 NMR Ultrashied AVANCE II equipment (spectrometer equipped with a solid probe), The ${ }^{29} \mathrm{Si}$ magic-angle spinning (MAS) measurements were carried out at frequencies of $79.5 \mathrm{MHz}$, and a spin speed of $5 \mathrm{KHz}$.

- The compressive strength of the pastes was tested at different ages of 28, 180, and 360 days using a Universal INSTRON model 3369 compression testing instruments. The displacement speed was $1 \mathrm{~mm} / \mathrm{min}$, and $2 \mathrm{~cm} \times 2 \mathrm{~cm} \times 2 \mathrm{~cm}$ cube samples were used. Three specimens were tested for each mixture and curing age.

- The tests performed on the blocks were density, water absorption and compressive strength, these were determined according the NTC 4026 standard, which applies for both structural and non-structural masonry units. The strength test was performed using an ELE international Soiltest press with a multi-channel data logger; the two channels corresponding to CT 930 and CT6200A had a maximum load capacity of $2000 \mathrm{kN}$ and $200 \mathrm{kN}$, respectively. Three specimens were evaluated for each test.

- The pavers were evaluated based on the technical requirements defined by the NTC 2017 standard; these requirements include absorption and flexural strength tests. The abrasion resistance of the material was determined according to the procedure described by NTC 5147 . 
The flexural strength of the paver was tested using a Universal INSTRON 3369 press that was equipped with specialized cells for this test. Three specimens were evaluated for each test.

\section{LIFE CYCLE ASSESSMENT (LCA) METHODOLOGY}

The LCA focused on six principal categories associated with environmental impacts and human health: the global warming potential (GWP 100; $\mathrm{kg} \cdot \mathrm{CO}_{2} \cdot \mathrm{eq}$ ), the acidification potential (AP; moles of $\left.\mathrm{H}^{+}-\mathrm{Eq}\right)$, the eutrophication potential $(\mathrm{EP} ; \mathrm{kg} \cdot \mathrm{N})$, the ozone depletion potential (ODP; CFC-11. eq), the photochemical oxidation potential (POP; $\mathrm{NO}_{\mathrm{x}} \cdot$ eq), and respiratory effects (RE; PM2.5). The functional unit used in this study was 1 ton of binder (FA/GBFS-SN, FA/GBFS-RN, FA/OPC-SN, and FA/OPC-RN); the proportions of each material were calculated according the mix design (Table 3). The paste with the lowest environmental impact GWP and REs was selected to produce the construction elements, masonry blocks and pedestrian pavers.

The cradle to gate model was used to limit the LCA study; environmental inventories downloaded from the Ecoinvent 3.2 database were analyzed using OpenLCA 1.6.3 software. The six above-mentioned categories were measured using the TRACI method in OpenLCA. The Ecoinvent model selected was an allocation cut-off system model, which was selected since it considers by-products to be recyclable.

The process used to produce alkaline activated pastes includes the following inputs: the raw materials, electricity, fuel, and water. Meanwhile, the outputs of this process include the following elements: air emissions, water emissions, soil emissions, and the product (i.e., 1 ton of binder). The life cycle phases considered included the material extraction, conditioning of the raw materials, and product manufacturing processes.

Figure 2 shows the initial raw material (i.e., waste or natural sources) and the manufacturing stages included in the LCA inventory to produce the FA, GBFS, and OPC. According to Habert et al. (20), FA, GBFS, and RHA were considered residues because they do not have applications or commercial value. These three waste products comprise LCA inventory conditioning stages that include grinding, crushing, and drying. OPC production involves limestone extraction, conditioning processes, clinkerization, and a final grinding step.

Figure 2 also shows the raw materials and processes used to produce the activators, alternative activators, and commercial SS. Sodium silicate can be manufactured by two routes: a hydrothermal "wet process" or a pyrometallurgical "liquid furnace" process. According to the SS supplier, this study used the liquid furnace route; values were extracted from Ecoinvent 3.2 inventory database.

The cementitious paste manufacturing process is shown in Figure 3. The process includes the homogenization of the raw materials (FA/GBFS and FA/OPC), addition of the alkaline activators, mixing, casting, and curing.

Table 3 shows the mass input values for each binder, and these values were used to measure the six impact categories.

Table 4 shows the category impacts for the electricity of the medium voltage $(\mathrm{kWh})$ used during the conditioning of the raw material; these impacts are also included in the input values.

\section{RESULTS AND DISCUSSION}

\subsection{Effect of the silica source on the microstructure and compressive strength of FA/GBFS and FA/OPC systems}

Figure 4 shows the microstructure of the four studied systems: FA/GBFS-SN, FA/GBFS-RN, FA/OPC-SN, and FA/OPC-RN, after 28 and 360 days of curing. Based on the SEM images, at the age of 28 days of curing, all samples exhibit a non-uniform surface; there were found dense and uneven areas, microcracks from drying shrinkage process, and some unreacted particles (marked

TABLE 3. Input values for each binder used in the LCA.

\begin{tabular}{lccccc}
\hline & & \multicolumn{3}{c}{ (kg material/ton binder) } \\
\cline { 3 - 6 } Raw materials & Items (kg) & FA/GBFS-SN & FA/GBFS-RN & FA/OPC-SN & FA/OPC-RN \\
\hline Precursors/ cementitious & FA & 399.77 & 372.14 & 449.36 & 438.40 \\
material & GBFS & 171.33 & 159.49 & - & - \\
& OPC & - & - & 112.34 & 109.60 \\
Alkaline activators & NaOH & 48.89 & 88.14 & 37.24 & 88.83 \\
\multirow{2}{*}{ Alternative source of silica } & SS & 263.11 & - & 308.99 & - \\
Water & RHA & - & 84.42 & - & 103.90 \\
\hline
\end{tabular}




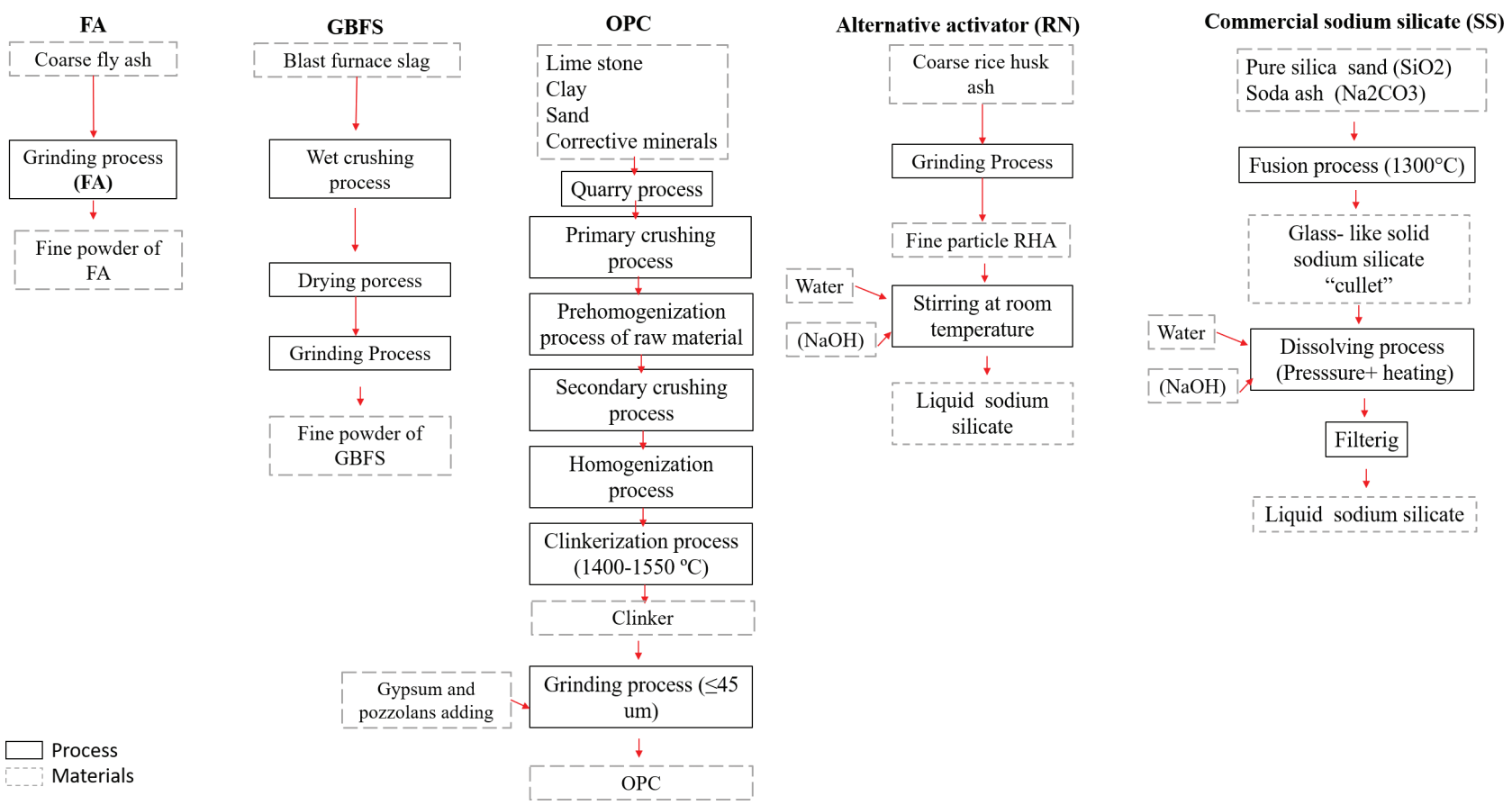

FIGURE 2. Manufacturing stages included in the LCA inventory of FA, GBFS, OPC, RN and SS.

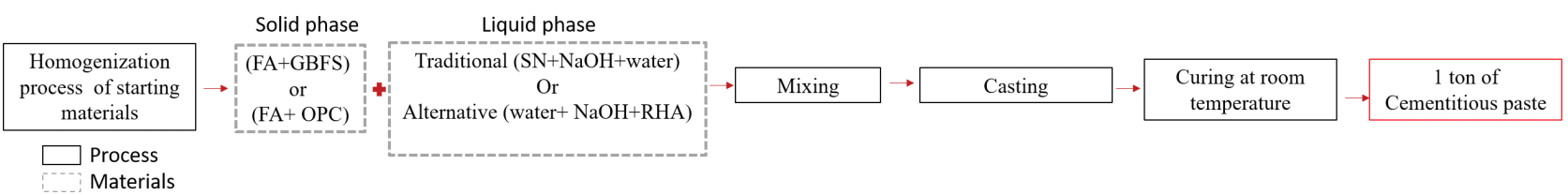

Figure 3. Cementitious paste manufacturing process.

TABLE 4. Energy category impacts and input values.

\begin{tabular}{lllll}
\hline & & \multicolumn{3}{c}{ Input values (kWh) } \\
\cline { 3 - 5 } $\begin{array}{l}\text { Category impacts for } \\
\text { energy consumption }\end{array}$ & $\begin{array}{c}\text { Drying } \\
\text { process }\end{array}$ & $\begin{array}{c}\text { Crushing } \\
\text { grinding } \\
\text { process }\end{array}$ & $\begin{array}{c}\text { Homogenization } \\
\text { process }\end{array}$ \\
\hline AP & 0.19 & & & \\
EP & $9.24 \times 10^{-5}$ & & & \\
GWP & 0.73 & & & \\
ODP & $2.35 \times 10^{-8}$ & $2.72 \times 10^{-2}$ & $3.65 \times 10^{-2}$ & $7.99 \times 10^{-2}$ \\
POP & $1.50 \times 10^{-3}$ & & & \\
RE & $1.95 \times 10^{-3}$ & & & \\
\hline
\end{tabular}

Acidity potential (AP); Eutrophication potential (EP); Global warming potential (GWP); Ozone depletion potential (ODP); Photochemical oxidation potential (POP); Respiratory effect (RE).

with a star) from FA which are characterized by having a spherical shape. Based on the observations, it is assumed that many of the unreacted particles are dissolved at the age of 360 days, becoming part of the reaction gels.
At the age of 28 days, RN systems have a more porous and uneven microstructure compare to $\mathrm{SN}$ type systems, which have a smoother and denser appearance. These results indicate that the dissolution of the particles in $\mathrm{SN}$ binders has a higher reaction degree than $\mathrm{RN}$ binders at an early age. At the age of 360 days, all the systems show a denser and a similar surface. It is worth noticing RN systems show a low reaction degree at an early age; at a more extended time, it reaches a comparable microstructure than SN. This performance agrees with the mechanical behaviour shown in Figure 6.

Elements such as $\mathrm{Si}, \mathrm{Al}, \mathrm{Na}, \mathrm{Ca}$, and $\mathrm{O}$, were detected by EDX (area marked in red) on both systems FA/GBFS and FA/OPC. Independent of the activator $\mathrm{RN}$ or $\mathrm{SN}$, the chemical elements with the higher participation on the selected area were $\mathrm{O}$ (28-43\%), Si (14-29\%) and $\mathrm{Ca}(3-33 \%)$; the elements with the lower participation were $\mathrm{Na}$ and $\mathrm{Al}$. The presence of the above-mentioned elements allowed authors to infer the co-existence of reaction products with $\mathrm{Si}-\mathrm{O}-\mathrm{Al}-\mathrm{Na}$ bonds and $\mathrm{Si}-\mathrm{O}-\mathrm{Ca}-\mathrm{Al}-\mathrm{Na}$ bonds arrangements. On the other hand, EDX analysis also indicates the presence of carbon (C) in a 
a)

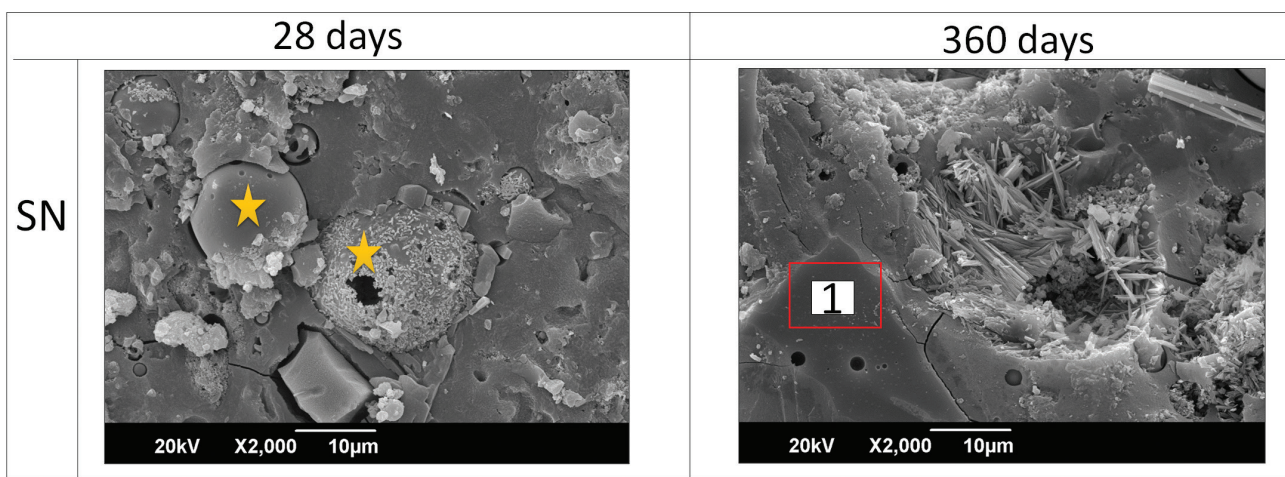

\begin{tabular}{|c|c|}
\hline $\begin{array}{c}\text { Element } \\
\text { \% wt }\end{array}$ & Spot $\mathbf{1}$ \\
\hline $\mathrm{C}$ & 8.2 \\
\hline $\mathrm{O}$ & 28.3 \\
\hline $\mathrm{Na}$ & - \\
\hline $\mathrm{Al}$ & 9.50 \\
\hline $\mathrm{Si}$ & 20.2 \\
\hline $\mathrm{Ca}$ & 33.8 \\
\hline Total & 100 \\
\hline
\end{tabular}

b)
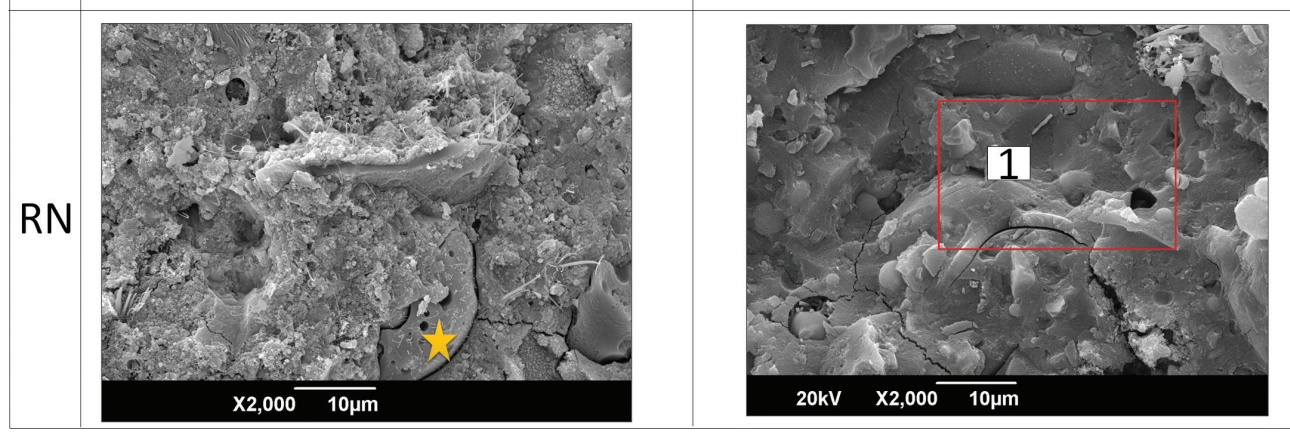

\begin{tabular}{|c|c|}
\hline $\begin{array}{c}\text { Element } \\
\text { \% wt }\end{array}$ & Spot 1 \\
\hline $\mathrm{C}$ & 23.4 \\
\hline $\mathrm{O}$ & 43.7 \\
\hline $\mathrm{Na}$ & 6.95 \\
\hline $\mathrm{K}$ & 0.72 \\
\hline $\mathrm{Al}$ & 4.63 \\
\hline $\mathrm{Si}$ & 14.8 \\
\hline $\mathrm{Ca}$ & 4.86 \\
\hline $\mathrm{Fe}$ & 0.94 \\
\hline Total & 100 \\
\hline
\end{tabular}

c)

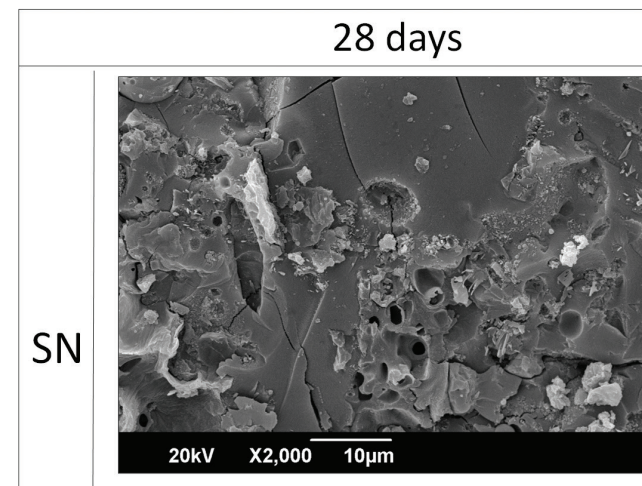

d)
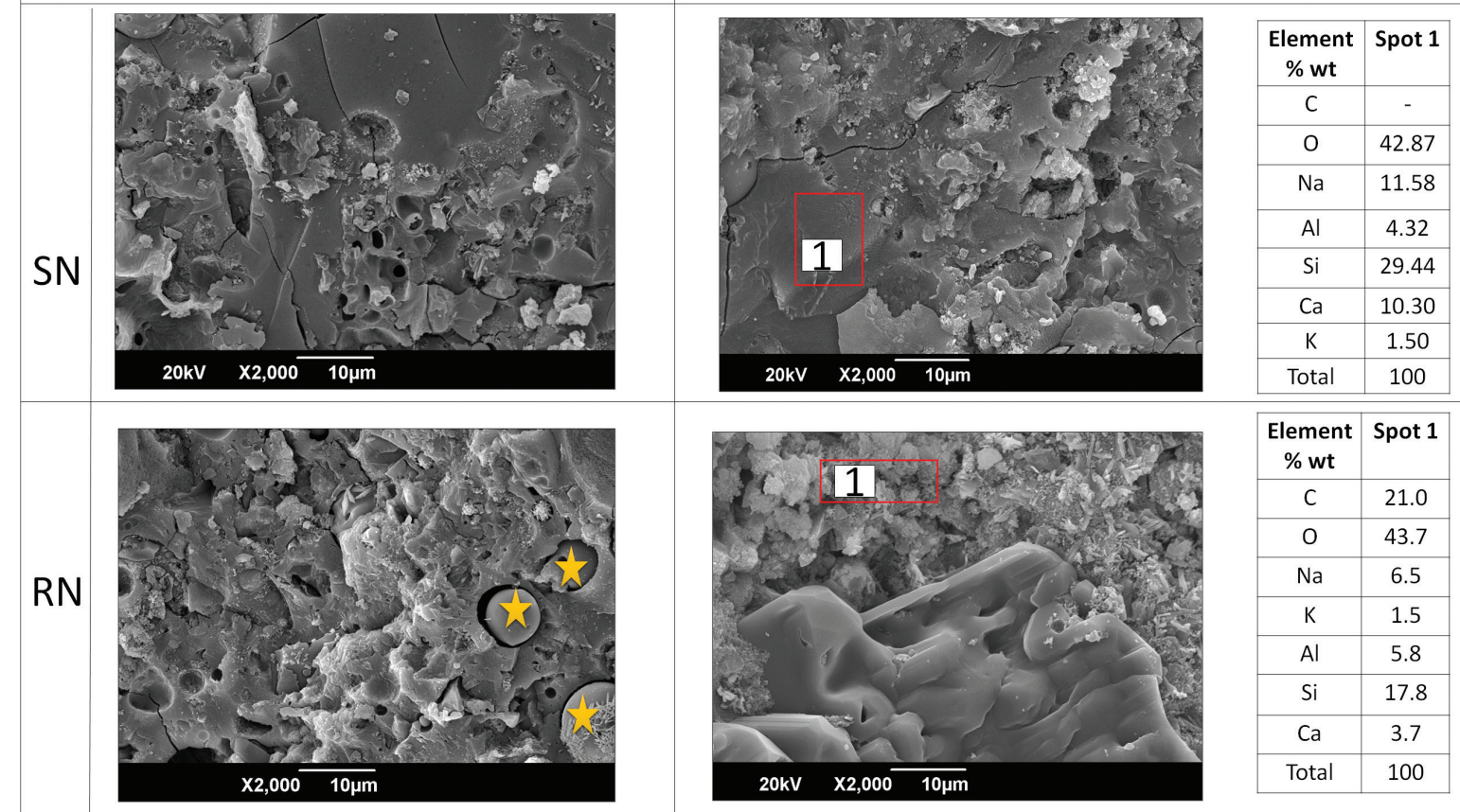

\begin{tabular}{|c|c|}
\hline $\begin{array}{c}\text { Element } \\
\text { \% wt }\end{array}$ & Spot 1 \\
\hline $\mathrm{C}$ & 21.0 \\
\hline $\mathrm{O}$ & 43.7 \\
\hline $\mathrm{Na}$ & 6.5 \\
\hline $\mathrm{K}$ & 1.5 \\
\hline $\mathrm{Al}$ & 5.8 \\
\hline $\mathrm{Si}$ & 17.8 \\
\hline $\mathrm{Ca}$ & 3.7 \\
\hline Total & 100 \\
\hline
\end{tabular}

FIGURE 4. SEM images of the alkaline-activated pastes: a) FA/GBFS-SN, b) FA/GBFS-RN, c) FA/OPC-SN, and d) FA/OPC-RN.

high percentage from $8-23 \%$; it is assumed to come from the high content of unburnt material in FA, which has a LOI of $14.96 \%$ (shown in table 1).

Figure 5 shows the ${ }^{29} \mathrm{Si}$ MAS NMR spectra of FA/GBFS (SN (a) and RN (b)) and FA/OPC (SN (c) and RN (d)) alkali-activated binders. Table 5 includes the percentages of participation of each silicate unit for each curing time 28 and 360 days. The values were calculated from the deconvolution of each spectrum following the Gaussian adjustment function; the regression coefficient $\left(\mathrm{R}^{2}\right)$ varies between 0.96 to 1 . 


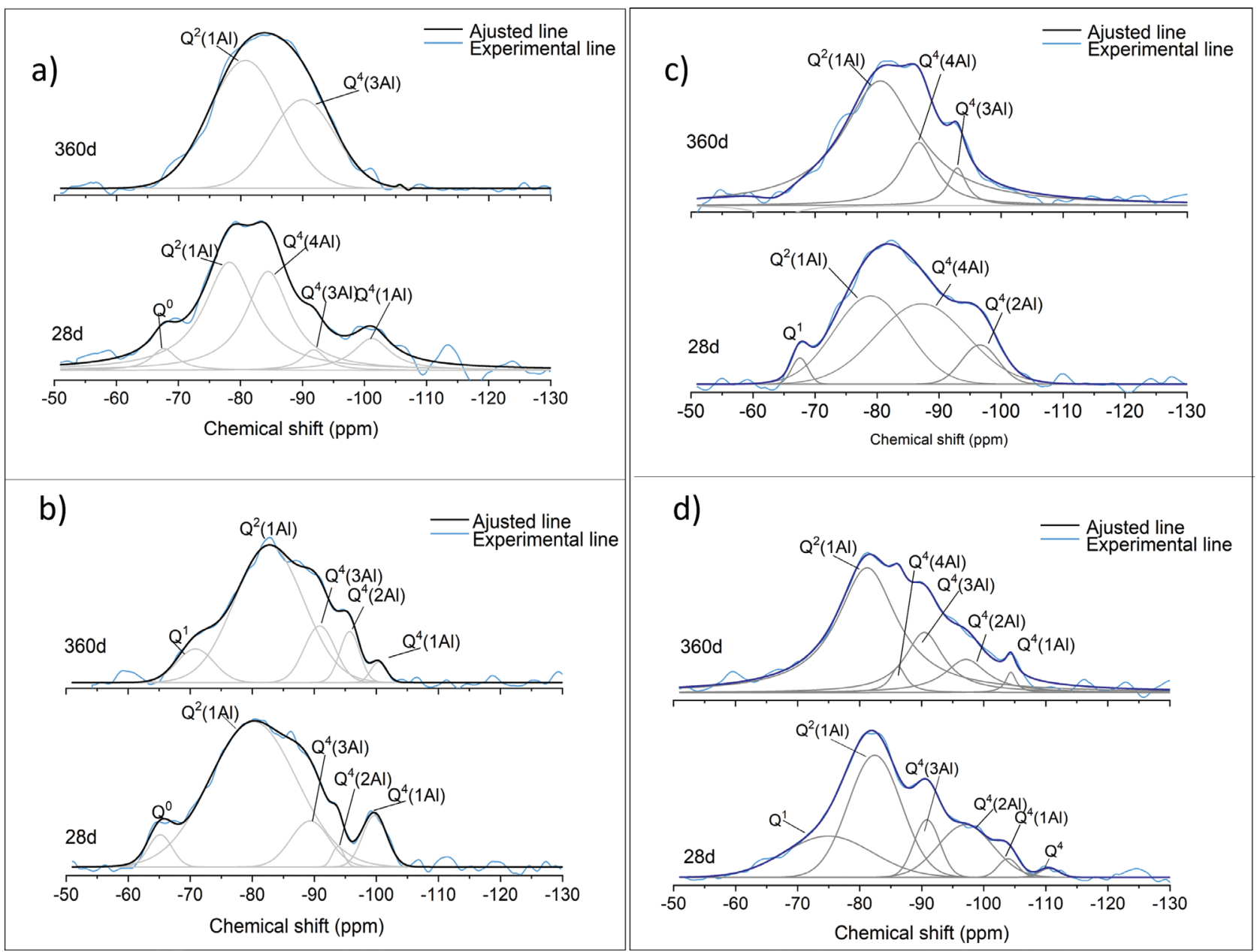

FIGURE 5. ${ }^{29}$ Si MAS-NMR spectra of binary and hybrid binders at 28 days and 360 days. a) FA/GBFS-SN, b) FA/GBFS-RN, c) FA/OPC-SN and d) FA/OPC-RN.

TABle 5. Percentage of participation of silicate units in each binder.

\begin{tabular}{lcccccccc}
\hline & \multicolumn{7}{c}{ Percentage (\%) } \\
\cline { 2 - 8 } Units & \multicolumn{2}{c}{ FA/GBFS-SN } & \multicolumn{2}{c}{ FA/GBFS-RN } & \multicolumn{2}{c}{ FA/OPC-SN } & \multicolumn{2}{c}{ FA/OPC-RN } \\
\cline { 2 - 9 } & $\mathbf{2 8}$ days & $\mathbf{3 6 0}$ days & 28 days & $\mathbf{3 6 0}$ days & 28 days & $\mathbf{3 6 0}$ days & 28 days & 360 days \\
\hline $\mathrm{Q}^{4}$ & 0.0 & 0.0 & 0.0 & 0.0 & 0.0 & 0.0 & 1.2 & 0.0 \\
$\mathrm{Q}^{4}(1 \mathrm{Al})$ & 9.8 & 0.0 & 7.5 & 2.3 & 0.0 & 0.0 & 2.5 & 1.8 \\
$\mathrm{Q}^{4}(2 \mathrm{Al})$ & 0.0 & 0.0 & 1.4 & 7.4 & 9.2 & 0.0 & 19.1 & 11.9 \\
$\mathrm{Q}^{4}(3 \mathrm{Al})$ & 4.1 & 38.3 & 10.8 & 12.8 & 0.0 & 5.6 & 9.9 & 19.7 \\
$\mathrm{Q}^{4}(4 \mathrm{Al})$ & 36.1 & 0.0 & 0.0 & 0.0 & 46.6 & 17.5 & 0.0 & 3.4 \\
$\mathrm{Q}^{2}(1 \mathrm{Al})$ & 45.4 & 61.7 & 75.8 & 68.5 & 41.5 & 76.9 & 43.2 & 63.2 \\
$\mathrm{Q}^{1}$ & 0.0 & 0.0 & 0.0 & 9.1 & 2.7 & 0.0 & 24.1 & 0.0 \\
$\mathrm{Q}^{0}$ & 4.6 & 0.0 & 4.6 & 0.0 & 0.0 & 0.0 & 0.0 & 0.0 \\
\hline
\end{tabular}

Based on the results from SEM images and NMR spectra, it is confirmed the co-existence of two types of gels in the binary and hybrid systems. These results are in agreement with Gao et al. (21), Wang and Scrivener (22), Mejía et al. (23) and
García-Lodeiro et al. (24), who also observed a sodium aluminum silicate hydrate gel (N-A-S-H), calcium sodium aluminum silicate hydrate gel $(\mathrm{C}, \mathrm{N})$ A-S-H), and a modified calcium (aluminum) silicate hydrate gel (C-(A)-S-H) in alkali-activated Ca-rich 
systems based on fly ash, ground blast furnace slag and Portland cement. N-A-S-H and (C,N)-A-S-H gels results from the activation of $\mathrm{FA}$, the latter in presence of a calcium source; and (C-(A)-S-H) is generated from the activation of GBFS and OPC in the presence of FA. In the traditional hydration of OPC, the final product is a C-S-H gel with a $2 \mathrm{D}$ structure that does not contain aluminium.

The spectra on Figure 5 and the values included in table 5 show that $\mathrm{SN}$ activator promotes the formation in similar proportions of $\mathrm{N}-\mathrm{A}-\mathrm{S}-\mathrm{H},(\mathrm{C}, \mathrm{N})-$ A-S-H and calcium gels and C-(A)-S-H at an early age (28 days), the sum of all $\mathrm{Q}^{4}(1 \mathrm{Al}, 2 \mathrm{Al}, 3 \mathrm{Al}$, and $4 \mathrm{Al}$ ) resulted in the participation of $50 \%$ and $55 \%$, where $\mathrm{Q}^{4}(4 \mathrm{Al})$ units have the lower participation; units $\mathrm{Q}^{2}(1 \mathrm{Al})$ represents 45 and $41 \%$ in $\mathrm{FA} /$ GBFS-SN and FA/OPC-SN respectively. On the other hand, the activator RN leads to the formation of C-(A)-S-H gels represented by $\mathrm{Q}^{2}(1 \mathrm{Al})$ units over a N-A-S-H or $(\mathrm{C}, \mathrm{N})-\mathrm{A}-\mathrm{S}-\mathrm{H}$ gels at the age of 28 days, the calculated percentage fluctuated from $76 \%$ to $43 \%$ for FA/GBFS-RN and FA/OPC-RN respectively. Probably due to the low reactivity of silica in rice husk ash, the alkaline solution initially attacks secondary sources rich in calcium, promoting the formation of calcium gel. From the results, it is proposed that silica from RHA reacts slowly compared to the soluble silica present in sodium silicate.

The NMR spectra associated with binary and hybrid SN and RN type systems show at the age of 360 days, a decrease of the intensity and area of the signals related to $\mathrm{Q}^{4}(4 \mathrm{Al})$ units; also it is observed increase of $\mathrm{Q}^{4}(3 \mathrm{Al})$ percentage compared to the binders at 28 days. This behaviour states that gel $(\mathrm{C}, \mathrm{N})-\mathrm{A}-\mathrm{S}-\mathrm{H}$ is enriched in silica over time and decreases the amount of aluminium tetrahedrons in the structure of the tectosilicate. It is inferred that the aluminium species are probably bound in the $2 \mathrm{D}$ structure of gel $\mathrm{C}-(\mathrm{A})-\mathrm{S}-\mathrm{H}$, increasing the cross-linking and the central units $Q^{2}(1 \mathrm{Al})$ of the chain. Additionally, it was found that and age of 360 days of curing, $\mathrm{Q}^{2}(1 \mathrm{Al})$ units in all the binders (FA/GBFS-SN and RN; FA/OPC-SN and RN) increase its participation occupying around of $60 \%$ to $70 \%$, these results allow to assume that C-(A)$\mathrm{S}-\mathrm{H}$ gel, at extended ages has the majority occupation in the cementitious matrices.

On the other hand, at the age of 360 days, a dissolution of the unreacted species $\mathrm{Q}^{4}(0 \mathrm{Al})$ from FA and RHA, $\mathrm{Q}^{0}$ and $\mathrm{Q}^{1}$ units from slag and Portland cement, was observed. Wang and Scrivener (22) suggest that the dissolution of the species increases the length of the C-(A)-S-H gel chains and densify the structure.

Figure 6 shows that, at an early curing age (7 days), the compressive strength of the pastes is between 20 and $38 \mathrm{MPa}$. For systems with added GBFS, the type of silica source did not have a significant effect on the mechanical performance of

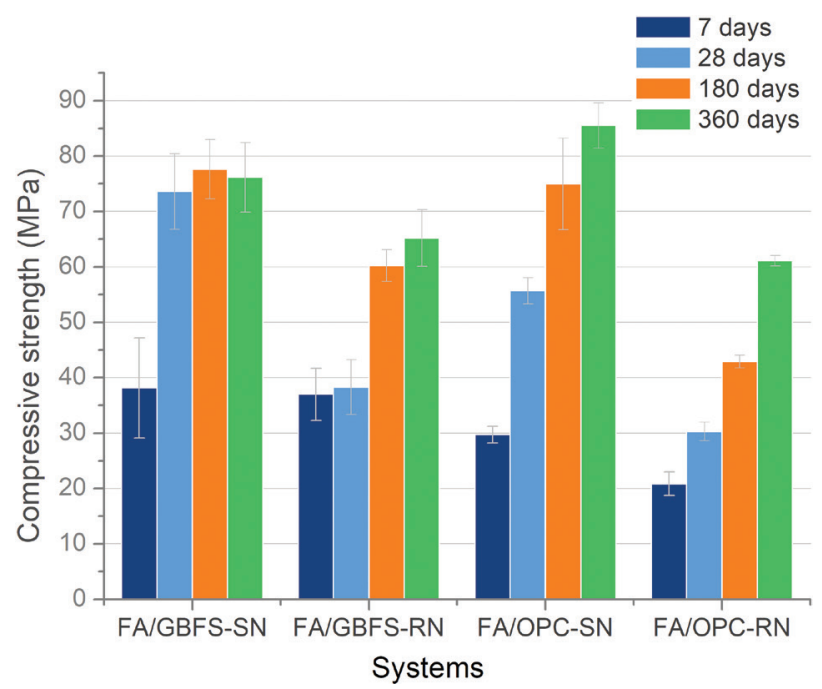

Figure 6. Compressive strength of the alkaline-activated pastes.

the resulting materials for short aging durations; the difference between the compressive strength of $\mathrm{SN}$ and $\mathrm{RN}$ was only $2 \mathrm{MPa}$; for the pastes with added $\mathrm{OPC}$, the difference between the compressive strength of the SN and RN systems was approximately $9 \mathrm{MPa}$. For both FA/GBFS and FA/OPC systems, the use of $\mathrm{RN}$ as alkali activator led to achieved low compressive strength compared to SN systems. This effect can be attributed to the low content of soluble silica present in RN. Previous studies have reported that FA/GBFS binary systems prepared using RHA as a source of silica and higher quality ash have compressive strengths similar to those reported in this study (i.e., $35 \mathrm{MPa}$ for materials after 7 days of curing) (23).

After 28 days, the pastes made with the SN activator ( $\mathrm{SS}+\mathrm{NaOH}$ ) had higher compressive strengths than the pastes made with the RN activator $(\mathrm{RHA}+\mathrm{NaOH})$. The FA/GBFS-SN system cured for 28 days had a strength that was $96 \%$ of the compressive strength of the FA/GBFS-SN pastes cured for 360 days. On the other hand, the compressive strength of FA/OPC-SN at 28 days was $64 \%$ of the final strength at 360 days. This behavior indicates that GBFS reacts more quickly in the alkaline medium than OPC, even though the proportion of OPC is only $20 \%$ compared to the $30 \%$ of GBFS in the systems studied. In the RN systems, the reactive silica present in the RHA $(36 \%)$ participates in the reaction in the early stages of aging (i.e., 7 and 28 days).

For extended periods of aging (i.e., 360 days), the FA/GBFS-RN and FA/OPC-RN systems have strengths of $65 \mathrm{MPa}$ and $61 \mathrm{MPa}$, respectively, which are up to twice the strength reported by these mixtures at 28 days. Geraldo et al. (25) reported a significant evolution of the compressive strength from 
28 to 90 days when MK-geopolymers are activated using sodium silicate based on RHA. It should be noted that in the SN systems, the high content of soluble silica imparts the material with high strengths of up to $85 \mathrm{MPa}$ at the same curing age. The strengths of FA/GBFS-RN and FA/OPC-RN at 360 days were $13 \%$ and $28 \%$ lower than SN-activated specimens. A study using silica sources as RHA $\left(88 \% \mathrm{SiO}_{2}\right)$ and microsilica was developed by Luukkoven et al. (12), the authors demonstrated that silica availability in the alkali-activated blast-furnace slag mortar affects compressive strength over time. However, their results were $32-34 \mathrm{MPa}$ at $28 \mathrm{~d}$; these values are comparable to those obtained in the present study.

Passuello et al. (17) evaluated the replacement of SS for RHA in geopolymers based on calcined kaolin sludge and reported comparable compressive strength $(<5 \%$ difference). These values coincide with the results reported by Bouzon et al. (26) and Villaquirán-Caicedo (9), who evaluated the compressive strength of geopolymer mortars based on fluid catalytic cracking catalyst (FCC) and alkaliactivated pastes based on metakaolin, respectively. The results reported for the authors were approximately $41 \mathrm{MPa}$ at 7 days of curing $(9,26)$. Bernal et al. (27) studied alkali-activated slag binders activated with silicate obtained from the chemical reaction between $\mathrm{NaOH}$ and RHA; these pastes reported higher compressive strength than those produced with commercial sodium silicate. It should be noted that all the studies mentioned have used RHA obtained at controlled conditions $\left(600^{\circ} \mathrm{C}\right)$, which allowed high percentages of soluble silica $(>60 \%)$. On the contrary, in the present study, RHA is from an industrial combustor and has $36 \%$ of soluble silica in $\mathrm{NaOH}$.

\subsection{Effect of the silica source on the life cycle analysis of the FA/GBFS and FA/OPC systems}

Table 6 shows the five categories analyzed in the LCA study and the impact values associated with each raw material; these values are given for
$1 \mathrm{~kg}$ of material. Because FA and RHA are classified as "waste," no inventory of the environmental impacts produced by them exists, and for this reason, FA and RHA are not included in the table. The only values that can be used to calculate the total binder impact of FA and RHA is the energy consumed while preparing FA and RHA; this energy was shown in Table 4.

The values shown in Table 6 are associated with the emission inventories of the raw materials, showing the materials with the most significant individual environmental impact; the results show that $\mathrm{NaOH}$ is the component with the highest adverse incidence. In general, the values in Table 6 show that, in the alkaline-activated materials, the alkaline solution is the most polluting component. Other authors, such as Passuello et al. (17), Petrillo et al. (28), and Tempest et al. (29), have also shown the alkaline solution to be the most polluting component of alkaline-activated materials. SS is produced by a liquid furnace process and requires the use of natural resources and high temperatures of approximately $1300^{\circ} \mathrm{C}$ (Figure 2). On the other hand, sodium hydroxide is produced by electrolysis in a diaphragm cell. Both processes release large amounts of $\mathrm{CO}_{2}$ into the atmosphere and require large amounts of energy. With regards to calcium sources, the environmental impact of OPC is higher than that of GBFS because of the process used to extract the natural raw materials, the high energy used during the clinkering process, and the $\mathrm{CO}_{2}$ emissions generated in the same process.

Figure 7 shows the impact of each raw material (represented as a percent) in the four designed binders (Table 3). Because the impact percentages of FA, RHA, and GBFS are lower than that of water, which has an impact percentage between $0.1 \%$ and $0.01 \%$ (represented by the thin red bar at the top of the columns), the bars assigned to these materials are not visible.

The total impact percentage of the SS in the FA/ GBFS-SN and FA/OPC-SN systems for all categories was between $70 \%$ and $86 \%$, with the exception

TABLE 6. Category impact values for each raw material.

\begin{tabular}{|c|c|c|c|c|c|c|}
\hline \multicolumn{3}{|c|}{$\begin{array}{l}\text { Category impacts per } 1 \mathrm{~kg} \\
\text { of material }\end{array}$} & \multicolumn{3}{|c|}{ Raw materials and category values } & \multirow[b]{2}{*}{ Water } \\
\hline & Units & GBFS & OPC & $\mathrm{NaOH}$ & SS & \\
\hline $\mathrm{AP}$ & moles of $\mathrm{H}^{+}-\mathrm{Eq}$ & 0.03 & 0.10 & 0.37 & 0.35 & $1.78 \times 10^{-4}$ \\
\hline EP & $\operatorname{kg~N}$ & $1.13 \times 10^{-5}$ & $9.64 \times 10^{-5}$ & $2,73 \times 10^{-4}$ & $3,22 \times 10^{-4}$ & $1.01 \times 10^{-7}$ \\
\hline GWP & $\mathrm{kg} \mathrm{CO}_{2}$-Eq & 0.073 & 0.90 & 1.33 & 1.17 & $6.51 \times 10^{-4}$ \\
\hline ODP & kg CFC-11-Eq & $4.60 \times 10^{-9}$ & $2.14 \times 10^{-8}$ & $7.09 \times 10^{-7}$ & $5.60 \times 10^{-8}$ & $2.86 \times 10^{-11}$ \\
\hline POP & kg NOx-Eq & $1.66 \times 10^{-4}$ & $1.37 \times 10^{-3}$ & $2.91 \times 10^{-3}$ & $2.46 \times 10^{-3}$ & $1.51 \times 10^{-6}$ \\
\hline RE & $\mathrm{kg} \mathrm{PM}_{2.5}-\mathrm{Eq}$ & $2.67 \times 10^{-4}$ & $4.97 \times 10^{-4}$ & $3.48 \times 10^{-3}$ & $1.70 \times 10^{-3}$ & $1.63 \times 10^{-6}$ \\
\hline
\end{tabular}

Acidity potential (AP); Eutrophication potential (EP); Global warming potential (GWP); Ozone depletion potential (ODP); Photochemical oxidation potential (POP); Respiratory effect (RE). 
being the ozone depletion potential (ODP) category, which contributes to between 29 and $37 \%$ of the impact. In this category, sodium hydroxide has a higher impact, between $57 \%$ and $70 \%$, due to the raw materials used to produce $\mathrm{NaOH}$; these materials are rich in chlorinated compounds. The emission of chlorofluorocarbon gases (CFCs), which threaten the ozone layer during the manufacturing process of $\mathrm{NaOH}$, also contributes to its impact. In the $\mathrm{SN}$ systems, $\mathrm{NaOH}$ only contribute to between $8 \%$ and $27 \%$ of the impact, which depends on the impact category because the amount of $\mathrm{NaOH}$ is lower than that of SS in the system (Table 3); however, in the FA/GBFS-RN systems, $\mathrm{NaOH}$ has an impact percentage close to $99 \%$ due to the absence of a silicate. When OPC is incorporated as the calcium source, the environmental footprint increases.

Figure 8 shows the total results of the impact categories evaluated for each binder. It is observed that, except ODP, the mixes using $\mathrm{RN}(\mathrm{RHA}+\mathrm{NaOH})$ as activator have lower impacts in AP, GWP, EP, POP and RE. RN systems reduce the environmental impact by $50 \%$ to $75 \%$ compared to $\mathrm{SN}$ systems

However, the ozone depletion potential (ODP) increased up to $34 \%$ in $\mathrm{RN}$-activated specimens. In this study, the paste with the greatest impact was FA/ OPC-SN, which had a GWP of $514.18 \mathrm{~kg} \cdot \mathrm{CO}_{2} \cdot$ eq. Specially, GWP is reduced up to $61 \%$; this coincides with Habert et al. (20), who demonstrated that replacing traditional SS with alternative sources

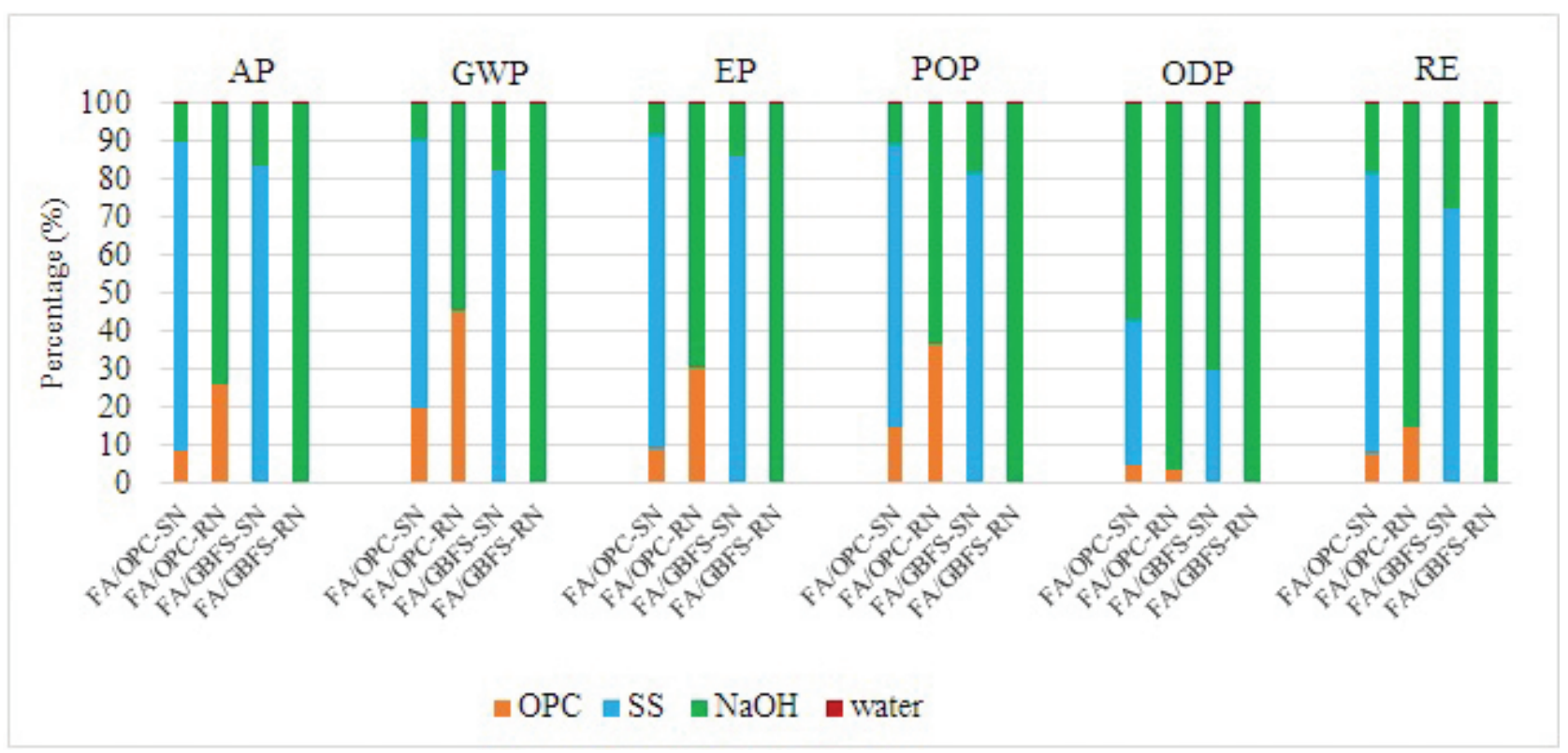

FigURE 7. Percentage of impact per raw material for each binder.

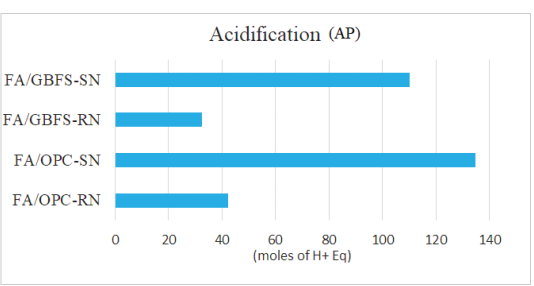

Photochemical oxidation (POP)

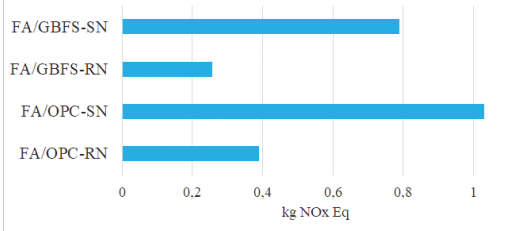

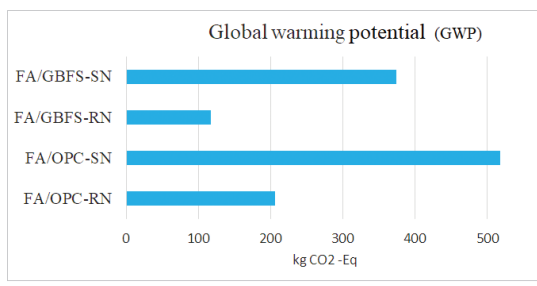

Ozone depletion (ODP)

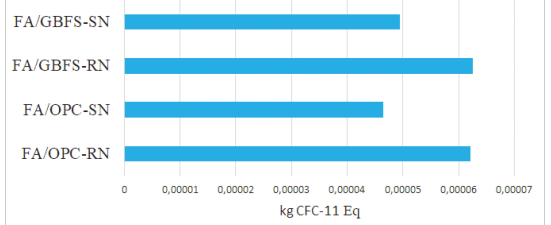

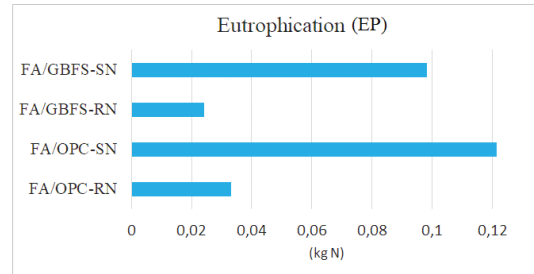

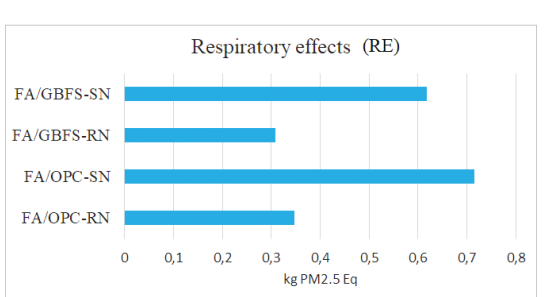

FIGURE 8. Impact categories of each binders. 
of silica substantially reduces the global warming potential of the product. The environmental results reported in this article agree with those reported by Passuello et al. (17), who worked with an alkalineactivated kaolin sludge residue and used RHA as the silica source, authors also concluded that using RHA decreases the environmental impact in several categories. (AP, GWP, EP, and POCP). VillaquiranCaicedo and Mejía de Gutiérrez (30) reported that the global warming potential emissions were reduced by $47.45 \%$ when is replaced $100 \%$ SS by RHA in the activator in metakaolin-based geopolymers.

Comparing the sources of calcium in in the system evaluated (OPC and GBFS), the Figure 8 shows that the systems manufactured with FA/GBFS show a reduction between $11 \%$ and $42 \%$ in all the impact categories, which makes FA/GBFS less impactful than the FA/OPC systems. Therefore, from an environmental perspective, OPC is not a suitable alternative source of calcium. In this case, GBFS is a better alternative source of calcium, which is an industrial by-product.

The mechanical tests and life cycle analysis indicate the feasibility of replacing a traditional silica source with RHA without significantly affecting the mechanical performance of the material. The construction material produced using these systems has added value from the perspective of environmental sustainability and human health.

For construction materials to be deemed sustainable and certified by Cradle to Cradle ${ }^{\circledR}$, LEED ${ }^{\circledR}$, among other, waste (including fly ash, slag, and RHA) must be used as the main component of the materials produced, and the impact categories mentioned in this study should be reduced by at least $20 \%$ compared to traditional materials. Previous studies show that, in most cases, alkaline-activated materials have less impact in the GWP category compared with OPC-based construction materials; Robayo-Salazar et al. (31) reported a $44.7 \%$ reduction in the GWP of concretes made with alkaline-activated natural pozzolan $\left(210.90 \mathrm{~kg} \mathrm{CO}_{2}\right.$ $\mathrm{eq} / \mathrm{m}^{3}$ ) compared to a traditional concrete based on Portland cement $\left(381.17 \mathrm{~kg} \mathrm{CO}_{2} \mathrm{eq} / \mathrm{m}^{3}\right)$. Bricks prepared with alkaline-activated materials composed of red clay brick waste had GWP reductions of up to $73 \%$ compared to ceramic bricks produced from clay (32).

\subsection{Viability of using an alkali activated binary mortar to produce masonry and paver elements}

Based on the results obtained in the life cycle assessment and considering the GWP and RE categories, the FA/GBFS-RN paste was selected as the optimal material for producing the block and paver construction material because it had the lowest GWP $\left(117.06 \mathrm{~kg} \cdot \mathrm{CO}_{2} \cdot\right.$ eq $)$ and $\operatorname{RE}\left(0.30 \mathrm{~kg} \mathrm{PM}_{2.5}\right.$-eq $)$ impact among the four systems studied. The proportions of the mix design of the masonry blocks and pedestrian pavers are included in Table 7.

Figure 9 (a) shows the manufactured block. The masonry element has an excellent finish, the dimensions of the produced block were $30 \mathrm{~cm} \times 15 \mathrm{~cm}$ $\times 11 \mathrm{~cm}$, and the wall thickness between the holes and the surface was $4 \mathrm{~cm}$. Figure 9 (b) shows the

TABLE 7. Proportions of the mix design of the masonry blocks and pedestrian pavers.

\begin{tabular}{lcccccc}
\hline & \multicolumn{7}{c}{ kg of material } \\
\cline { 2 - 7 } Element & FA & GBFS & RHA & NaOH & Sand & Water \\
\hline Masonry Block & 1750 & 750 & 397 & 414.7 & 2500 & 1490.3 \\
Pedestrian paver & 1750 & 750 & 397 & 414.7 & 2500 & 1258.5 \\
\hline
\end{tabular}

a)

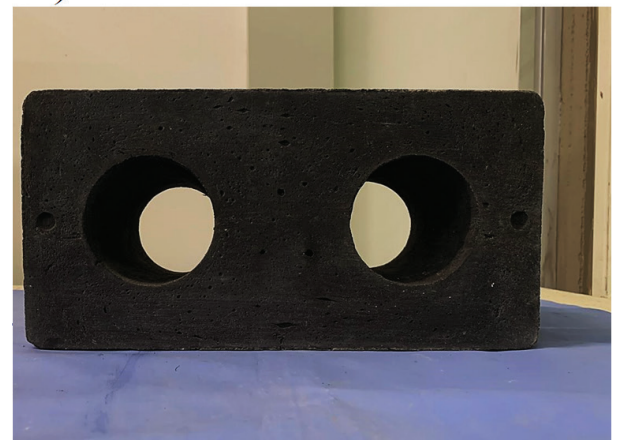

b)

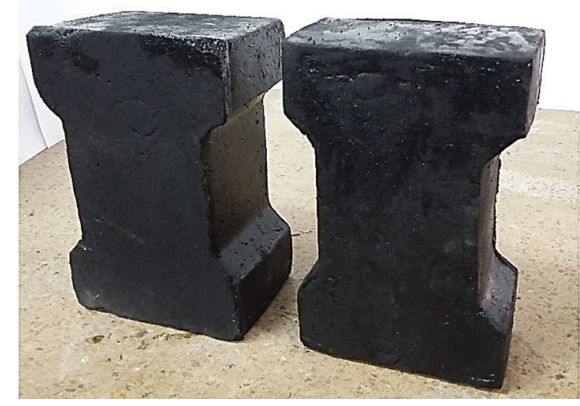

FIGURE 9. a) Masonry block and b) pedestrian paver composed of FA/GBFS-RN mortar. 
TABLE 8. Mechanical and physical properties of the materials after curing for 28 days.

\begin{tabular}{lllc}
\hline Material & \multicolumn{1}{c}{ Property } & \multicolumn{1}{c}{ Specification } & Results \\
\hline NTC 4026 & Compressive strength $(\mathrm{MPa})$ & 13 & $16.7 \pm 0.72$ \\
Block & Density $\left(\mathrm{kg} / \mathrm{m}^{3}\right)$ & Between 1680 and 2000 & $1894 \pm 16.90$ \\
& Absorption (\%) & 12 & $8,1 \pm 1.14$ \\
Pedestrian paver & Flexural strength (MPa) & $4.2-5$ & $4.3 \pm 0.88$ \\
NTC 2017 & Absorption (\%) & Maximum 7 & $6.63 \pm 0.25$ \\
& Track length (mm) & Maximum 23 & $20.4 \pm 1.3$ \\
\hline
\end{tabular}

geometry of the pedestrian pavers; according to standard NTC 2017, the pedestrian paver is classified as type 2 with an I-shape. The dimensions of the paver were $20 \mathrm{~cm} \times 13 \mathrm{~cm} \times 9 \mathrm{~cm}$, and the inscribed rectangle was $20 \times 9 \mathrm{~cm}$ (where the nominal length/ nominal width ratio was 2.2).

According to the requirements established by Colombian technical standards NTC 4026 and NTC 2017, the masonry block and the pedestrian paver were mechanically and physically evaluated, and the specifications are presented in Table 8. The Colombian standard classifies blocks as either structural or non-structural, depending on the compressive strength. According to this criterion, the masonry material developed is classified as a structural block with a medium weight $\left(1894 \mathrm{~kg} / \mathrm{cm}^{3}\right)$ and high compressive strength $(16.7 \mathrm{MPa})$. The paver meets the NTC 2017 requirements. The paver surface showed good wear performance, demonstrating that this material can be placed in high-traffic areas with little risk of wearing. Additionally, the absorption percentage indicates a good response when exposed to the elements.

The results obtained for the block are comparable to studies conducted by Palomo and FernándezJiménez (33), who manufactured blocks from an FA/OPC hybrid. Robayo-Salazar et al. (32) developed blocks meeting Colombian technical standards (NTC) from a hybrid system composed of brick waste and 10\% Portland cement, and the compressive strength achieved by this hybrid system was equivalent to that of the FA/GBFS-RN binary mixture block, which was $16 \mathrm{MPa}$. Higher compressive strengths were reported by Kishan and Radhakrishna (7), who activated a binary mixture of FA/GBFS using as activator $\mathrm{SS} / \mathrm{NaOH}$ to produce masonry blocks and reported a compressive strength of $25 \mathrm{MPa}$ after 28 days of curing. On the other hand, Suksiripattanapong et al. (34) designed a block with municipal sludge and alkaline-activated FA, and the strength was $20 \mathrm{MPa}$ after thermal curing at $75^{\circ} \mathrm{C}$.

It is worth noting that few publications have reported manufacturing alkaline-activated pedestrian pavers composed of wastes or alkaline-activated by-products. Robayo-Salazar et al. (32) used a mixture of brick waste and Portland cement and obtained a flexural strength and water absorption of $4.42 \mathrm{MPa}$ and $6.5 \%$, respectively. Kumar and Kumar (35) developed pavers for pavement from an FA/red sludge system and reported a compressive strength of $30 \mathrm{MPa}$.

\section{CONCLUSIONS}

The results obtained in this study show the feasibility of using FA with a high unburned carbon $(14.96 \%)$ as a precursor and RHA generated as a by-product in a combustor ( $36 \%$ soluble silica) as a silica source to replace commercial SS in alkalineactivated materials. The compressive strength of the FA/GBFS-RN and FA/OPC-RN systems after curing for 28 days was 38 and $30 \mathrm{MPa}$, respectively, while after curing for 360 days, the compressive strength of the FA/GBFS-RN and FA/OPC-RN systems increased to 65 and $61 \mathrm{MPa}$, respectively. These values indicate that FA/GBFS-RN is a suitable binder for manufacturing mortar-based prefabricated materials.

NMR analysis leads to identified that $\mathrm{SN}$, activator promotes the formation at an early age (28 days) of (C,N)-A-S-H, N-A-S-H and C-(A)-S-H gels in both analyzed systems (FA/GBFS and FA/OPC). RN systems at the same age exhibited an opposite behavior, it leads mainly to the formation of C-(A)$\mathrm{S}-\mathrm{H}$ gel represented by $\mathrm{Q}^{2}(1 \mathrm{Al})$ units. At extended ages (360 days) SN systems show a decrease of $\mathrm{Q}^{4}(4 \mathrm{Al})$ and an increase of $\mathrm{Q}^{4}(3 \mathrm{Al})$ units this behavior states that N-A-S-H gel is transformed into $(\mathrm{C}, \mathrm{N})-\mathrm{A}-\mathrm{S}-\mathrm{H}$, this latter is enriched in silica over time, decreasing the amount of aluminum tetrahedrons in the structure of the tectosilicate. At the same age, it was detected in all the binders an increase of the percentage of $\mathrm{Q}^{2}(1 \mathrm{Al})$ units from 60 to $76 \%$; it is assumed that the aluminum species from $\mathrm{Q}^{4}(4 \mathrm{Al})$ and $\mathrm{Q}^{4}(3 \mathrm{Al})$ are reorganized and bound in the $2 \mathrm{D}$ structure of the C-(A)-S-H gel, increasing the crosslinking and the central units $\mathrm{Q}^{2}(1 \mathrm{Al})$ of the chain.

Finally, a reduction between $50 \%$ and $75 \%$ of the environmental and health impact categories was identified when an alternative activator prepared mixing RHA and $\mathrm{NaOH}$ was used in the 
manufacture of alkali-activated binders based on FA. The optimal paste (i.e., FA/GBFS-RN) reported GWP and $\mathrm{RE}$ values of $117.06 \mathrm{~kg} \cdot \mathrm{CO}_{2} \cdot \mathrm{eq}$ and $0.30 \mathrm{~kg}$ PM2.5-eq, respectively. The feasibility of producing eco-efficient prefabricated blocks, and pavers that meet the requirements of the Colombian Technical Standards (NTC) was demonstrated.

\section{ACKNOWLEDGMENTS}

The authors members of the Composite Materials Research Group (GMC) the Administrative Department of Science, Technology and Innovation (Colciencias) for the support received for the project, "Construction of prototype at the scale of rural housing using innovative materials with low carbon footprint," Contract 096- 2016. The authors also thank the Universidad del Valle (Cali, Colombia), institution where the study was realized.

\section{REFERENCES}

1. Guillaume, H.; Ouellet-Plamondonb, C. (2016) Recent update on the environmental impact of geopolymers. RILEM Technical Letters 1, 17-23.

2. Woszuk, A.; Bandura, L; Franus, W. (2019) Fly ash as low cost and environmentally friendly filler and its effect on the properties of mix asphalt. J. Clean. Prod. 235, 493-502. https://doi.org/10.1016/j.jclepro.2019.06.353.

3. Yao, Z.T.; Ji, X.S.; Sarker, P.K.; Tang, J.H.; Ge, L.Q.; Xia, M.S.; Xi, Y.Q. (2015) A comprehensive review on the applications of coal fly ash. Earth-Sci Rev. 141, 105-121. https:// doi.org/10.1016/j.earscirev.2014.11.016.

4. Gollakota, A.R.K.; Volli, V.; Shu, C-M. (2019) Progressive utilisation prospects of coal fly ash: A review. Sci. Total. Environ. 672, 951-989. https://doi.org/10.1016/j. scitotenv.2019.03.337.

5. Palomo, A.; Fernández-Jiménez, A. (2008) Nuevos cementos de bajo impacto ambiental. Caat Valencia. 114, 22-26.

6. Fernández-Jiménez A.; Palomo, Á. (2011) Propiedades y aplicaciones de los cementos alcalinos. Rev. Ing. Constr. 24, 213-232. https://doi.org/10.4067/S0718-50732009000 300001.

7. Kishan, L.J.; Radhakrishna (2013) Comparative study of cement concrete and geopolymer masonry blocks. IJRET: Int. J. Res. Eng. Technol, 361-365. https://doi.org/10.15623/ ijret.2013.0213068.

8. Ârı̈z, Ö.; Kilinc, K.; Tuncan, M.; Tuncan, A.; Kavas, T. (2010) Physical, mechanical and micro-structural properties of $\mathrm{F}$ type fly-ash based geopolymeric bricks produced by pressure forming process. Adv. Sci. Tech. 69, 69-74. https://doi.org/10.4028/www.scientific.net/AST.69.69.

9. Villaquirán-Caicedo, M. (2019) Studying different silica sources for preparation of alternative waterglass used in preparation of binary geopolymer binders from metakaolin/boiler slag. Constr. Buil. Mater. 227, 116621. https:// doi.org/10.1016/j.conbuildmat.2019.08.002.

10. Torres-Carrasco, M.; Puertas, F. (2015) Waste glass in the geopolymer preparation. Mechanical and microstructural characterization. J. Clean. Prod. 90, 397-408. https://doi. org/10.1016/j.jclepro.2014.11.074.

11. Font, A.; Soriano, L.; Reig, L.; Tashima, M.; Borrachero, M.; Monzó, J.; Payá, J. (2018) Use of residual diatomaceous earth as a silica source in geopolymer production. Mater. Lett. 223, 10-13. https://doi.org/10.1016/j.matlet.2018.04.010.

12. Luukkonen, T.; Abdollahnejad, Z.; Yliniemi, J.; Kinnunen, P.; Illikainen, M. (2018) Comparison of alkali and silica sources in one-part alkali-activated blast furnace slag mortar. J. Clean. Prod. 187, 171-179. https://doi.org/10.1016/j. jclepro.2018.03.202.

13. Tchakouté, H.K.; Rüsche, C.H.; Kong, S.; Ranjbar, N. (2016) Synthesis of sodium waterglass from white rice husk ash as an activator to produce metakaolin-based geopolymer cements. J. Build. Eng. 6, 252-261. https://doi.org/10.1016/j. jobe.2016.04.007.

14. Mellado, A.; Catalán, C.; Bouzón, N; Borrachero, M.V.; Monzó, J.M.; Payá, J. (2014). Carbon footprint of geopolymeric mortar: study of the contribution of the alkaline activating solution and assessment of an alternative route. $R S C A d v .4,23846-23852$. https://doi.org/10.1039/ C4RA03375B

15. Tchakouté, H.K.; Rüsche, C.H.; Kong, S.; Kamseu, E.; Leonelli, C. (2016) Geopolymer binders from metakaolin using sodium waterglass from waste glass and rice husk ash as alternative activator: A comparative study. Constr. Build. Mater. 114, 276-289. https://doi.org/10.1016/j.conbuildmat. 2016.03.184.

16. Tchakouté, H.K.; Rüsche, C.H.; Hinsch, M.; Djobo, J.N.Y.; Kamseu, E.; Leonelli, C. (2017) Utilization of sodium waterglass from sugar cane bagasse ash as a new alternative hardener for producing metakaolin-based geopolymer cement. Chem. Erde. 77, 257-266. https://doi.org/10.1016/j. chemer.2017.04.003.

17. Passuello, A.; Rodríguez, E.D.; Hirt, E.; Longhi, M.; Bernal, S.A.; Provis, J.L.; Kirchheim, A.P. (2017) Evaluation of the potential improvement in the environmental footprint of geopolymers using waste-derived activators. J. Clean. Prod. 166, 680-689. https://doi.org/10.1016/j.jclepro.2017.08.007.

18. Kamseu, E.; Beleuk à Moungram, L.M.; Cannio, M.; Billong, N.; Chaysuwan, D. Chinje Melo, U.; Leonelli, C. (2017) Substitution of sodium silicate with rice husk ash$\mathrm{NaOH}$ solution in metakaolin based geopolymer cement concerning reduction in global warming. J. Clean. Prod. 142, 3050-3060. https://doi.org/10.1016/j.jclepro.2016.10.164.

19. Mehta P.K. (1973) Siliceous ashes and hydraulic cements prepared there-from. Belgium; Patent 802909.

20. Habert, G.; d'Espinose de Lacaillerie, J.B; Roussel, N. (2011) An environmental evaluation of geopolymer based concrete production: reviewing current research trends. J. Clean. Prod. 19, 1229-1238. https://doi.org/10.1016/j. jclepro.2011.03.012.

21. Gao, X.; Yu, Q.L.; Brouwers, H.J.H. (2017) Apply ${ }^{29} \mathrm{Si}$, ${ }^{27} \mathrm{Al}$ MASS NMR and selective dissolution in identifying the reaction degree of alkali-activated slag-fly ash composites. Ceram. Int. 43, 12408 -12419. https://doi.org/10.1016/j. ceramint.2017.06.108.

22. Wang, S-D.; Scrivener, K.L. (2003) ${ }^{29} \mathrm{Si}$ and ${ }^{27} \mathrm{Al}$ NMR study of alkali-activated slag. Cem. Concr. Res. 33, 769-774. https://doi.org/10.1016/S0008-8846(02)01044-X.

23. Mejía, J.M.; Mejía de Gutiérrez, R.; Puertas, F. (2012) Rice husk ash as a source of silica in alkali-activated fly ash and granulated blast furnace slag systems. Mater. Construc. 63, 361-375. https://doi.org/10.3989/mc.2013.04712.

24. García-Lodeiro, I; Fernández-Jiménez A. Palomo, A (2013) Variation in hybrid cements over time. Alkaline activation of fly ash-portland cement blends. Cem. Concr. Res. 52, 111-122. http://doi.org/10.1016/i.cemconres.2013.03.022.

25. Geraldo, R.H.; Fernandes, L.F.R.; Camarini, G. (2017) Water treatment sludge and rice husk ash to sustainable geopolymer production. J. Clean. Prod. 149, 146-155. https://doi.org/10.1016/j.jclepro.2017.02.076.

26. Bouzón, N.; Payá, J.; Borrachero, M.V.; Soriano, L.; Tashima, M.M.; Monzó, J. (2014) Refluxed rice husk ash/ $\mathrm{NaOH}$ suspension for preparing alkali activated binders. Mater. Lett. 115, 72-74. https://doi.org/10.1016/j.matlet. 2013.10.001.

27. Bernal, S.A.; Rodríguez, E.D.; Mejía de Gutiérrez, R.; Provis, J. L. (2015) Performance at high temperature of alkali-activated slag pastes produced with silica fume and rice husk ash-based activators. Mater. Construcc. 65 [318], e049. https://doi.org/10.3989/mc.2015.03114. 
28. Petrillo, A.; Cioffi, R.; Ferone, C.; Colangelo, F.; Borrelli, C. (2016) Eco-sustainable geopolymer concrete blocks production process. Agric. Agric. Sci. Procedia. 8, 408-418. https://doi.org/10.1016/j.aaspro.2016.02.037.

29. Tempest, B.; Sanusi, O.; Gergely, J.; Ogunro, V.; Weggel, D. (2009) Compressive strength and embodied energy optimization of fly ash based geopolymer concrete. World of Coal Ash Conference in Lexington, KY USA 1-17.

30. Villaquirán-Caicedo, M.A.; Mejía de Gutiérrez, R. (2018) Synthesis of ceramic materials from ecofriendly geopolymer precursors. Mater. Lett. 230, 300-304. https://doi.org/ 10.1016/j.matlet.2018.07.128

31. Robayo-Salazar, R.; Mejía-Arcilla, J.; Mejía de Gutierrez, R.; Martínez, E. (2018) Life cycle assessment (LCA) of an alkali-activated binary concrete based on natural volcanic pozzolan: A comparative analysis to OPC concrete. Constr. Build. Mater. 176, 103-111. https://doi.org/10.1016/j. conbuildmat.2018.05.017.
32. Robayo-Salazar, R.A.; Mejía-Arcila, J.M.; Mejía de Gutierrez, R. (2017) Eco-efficient alkali-activated cement based on red clay brick wastes suitable for the manufacturing of building materials. J. Clean Prod. 166, 242-252. https://doi.org/10.1016/j.jclepro.2017.07.243.

33. Palomo, A.; Fernández-Jiménez, A. (2011) Alkaline Activation, Procedure for Transforming Fly Ash into New Materials. Part 1: Applications. Proceedings of World of Coal Ash. 1-14.

34. Suksiripattanapong, C.; Horpibulsuk, S.; Chanprasert, P.; Sukmak, P.; Arulrajah, A. (2015) Compressive strength development in fly ash geopolymer masonry units manufactured from water treatment sludge. Constr. Build. Mater. 82, 20-30. https://doi.org/10.1016/j.conbuildmat.2015.02.040.

35. Kumar, A.; Kumar, S. (2013) Development of paving blocks from synergistic use of red mud and fly ash using geopolymerization. Constr. Build. Mater. 38, 865-871. https://doi. org/10.1016/j.conbuildmat.2012.09.013. 